\title{
Malnutrition and Somatic Development: Application of Protocol of Mensuration to Evaluation of Indicators of Wistar Rats
}

\author{
Desnutrición y Evaluación del Desarrollo Somático: Uso del Protocolo de Medidas \\ para la Evaluación de los Indicadores en Rats Wistar \\ "Hilton Justino da Silva; "Karla Mônica Ferraz Teixeira de Barros; "Daniele Andrade da Cunha; \\ *** Francisco de Assis da Silva Santos; ${ }^{* * * *}$ Elisângela Barros Soares; ${ }^{* * * *}$ Clécia Natália de Siqueira da Silva; \\ **:*: Silvia Regina Arruda de Moraes \& *Raul Manhães de Castro
}

SILVA, H. J.; BARROS, K. M. F. T.; CUNHA, D. A.; SANTOS, F. A. S.; SOARES, E. B.; SILVA, C. N. S.; MORAES, S. R. A. \& MANHÃES DE CASTRO, R. Malnutrition and somatic development: Application of protocol of mensuration to evaluation of indicators of Wistar rats. Int. J. Morphol., 24(3):469-474, 2006.

SUMMARY: This study analyzed the consequence of malnutrition and/or serotoninergic manipulation during the period of fast growth of encephalon on the somatic development in rats. It was used the protocol of measurement of indicators of this development proposed by Silva et al., 2005. The protocol was applied from 1st to 21 st day and rats were breastfed by female which received control diet (commercial diet, Labina) with $23 \%$ of protein, normoproteic diet, nourished animals (Group Nourished - Nour), $n=15$ or were breastfed by female which after the delivery received hypoproteic diet (Regional Basic Diet - RBD), with $8 \%$ of protein, malnourished animals (Group Malnourished - Maln) $n=15$. It were observed in the group malnourished a decrease of corporal weight from 4th day, of latero-lateral axis of skull from 8th to 21st day, of antero-posterior axis of skull from 10th to 21st day, of longitudinal axis and length of tail from 7th to 21 st day of life ( $\mathrm{p} \leq 0,05$ ) The study emphasized the hypothesis that malnutrition in critical period of development, interferes on somatic development of rats. Besides that, it was emphasized that the use of protocols with definition of anatomic points and suitable choice of material and accuracy of measurements provide a higher uniformity in periods which were observed the deleterious effects in all studied axes.

KEY WORDS: Malnutrition; Somatic development; Wistar rat.

\section{INTRODUCTION}

A suitable supply of nutrients is a main factor for the maintenance of growth in all organic systems as well as the development of physiologic functions (Levitsky \& Barnes, 1972; Morgane et al., 1993).

The deficit in growth is a consequence frequently observed in organisms at development phase subjected to lack of nutrients mainly proteic (Frank, 1986).

Studies in humans (Rooso et al., 1970; GranthanMcGregor et al., 1987; Benefice et al., 1999) and experimental studies (Resnick et al., 1979; Morgane et al., 1993; Chen et al.,1995) showed that malnutrition mainly during lactation and gestation causes structural and functional alterations in various organic systems. Thus, malnutrition is one of main non-genetic factors which can affect the organic development (Morgane et al.).

The expression of somatic growth is a main aspect of development in the animal kingdom especially mammals (Smart \& Dobbing, 1971). Works realized in our laboratory used indicators of somatic growth to evaluate the variability of aggressions in the development of malnourished rats.

However, it was observed some difficulty to establish more accurate parameters in the collect of data in our studies. In order to find more objective standard for the measurement of indicators of somatic development it was proposed the

* Departamento de Nutrição, Universidade Federal de Pernambuco Recife, Brasil.

** Departamento de Fisioterapia, Universidade Federal de Pernambuco, Recife, Brasil.

*** Departamento de Anatomia, Universidade Federal de Pernambuco, Recife, Brasil.

**** Departamento de Fonoaudiologia, Universidade Federal de Pernambuco, Recife, Brasil. Sponsorship: CNPQ - Edital Universal - Process n ${ }^{\circ} 473535 / 2003-3$. 
protocol of Silva et al. (2005). The protocol considers the suitable use of the scapus of the pachymeter, suggesting the use of an instrument with better degree of accuracy and defining anatomic points as bases for the measurements.

The aim of this study is to investigate in rats the consequence of malnutrition on the somatic development according to the model proposed by Silva $e t$ al.

\section{MATERIAL AND METHOD}

Thirty male albino Wistar rats from the colony of Departamento de Nutrição da Universidade Federal de Pernambuco, Brazil were used. The animals were kept in an environment at a temperature of $23 \pm 1^{\circ} \mathrm{C}$, in a light cycle (6am to $6 \mathrm{pm}$ ) and darkness cycle (6pm to $6 \mathrm{am}$ ) constant. The animals had free access to filtered water and standard ration (LABINA - Purina do Brasil, with 23\% of protein).

The animals were divided initially into two groups according to nutritional manipulation: group nourished formed by young breastfed by female which received normoproteic diet ("LABINA" $-23 \%$ of protein) and group malnourished formed by young breastfed by female which received hypoproteic diet (Regonal Basic Diet of NE - 8\% of protein (Teodósio et al., 1990).

To establish the method, the animals were subjected to daily murinometric evaluations during 21 days (breastfeeding period), from $12 \mathrm{am}$ to $2 \mathrm{pm}$. The following measures were considered: latero-lateral axis of skull (LLAS); Antero-posterior axis of skull (APAS); Longitudinal Axis (LA); Length of tail (LT).

The protocol of mensuration of somatic development validated in this work was described by Silva et al. (2005) and considers anatomic points and more accurate methods to obtain the measures.

To obtain these measures it was used a stainless steel pachymeter, Starret with an accuracy of $0,02 \mathrm{~mm}$.

It was also considered the evaluation of corporal weight $(\mathrm{CW})$, using a digital eletronic balance Marte, model S- 4000 , with capacity of $2 \mathrm{~kg}$ and sensibility of $0,1 \mathrm{~g}$.

To statistical analysis was applied the test of Kolmogorov-Sminorv and the test of Cocharn to verify the normality of variance. Afterwards, it was used the test of Mann-Whithney or test " $\mathrm{t}$ " of Student to compare the two groups.
The procedures used in this study are according to the rules suggested by the Institute of Health Guide for Care and Use of Laboratory Animals and were approved by the Comitê de Ética em Experimentação Animal da Universidade Federal de Pernambuco - CEEA-UFPE (Process No 005603/ 2004-51).

\section{RESULTS}

Corporal Weight $(\mathrm{CW})$. The group Malnourished showed decrease $(p<0,05)$ of corporal weight from $4^{\text {th }}$ to $21^{\text {st }}$ day when compared with the group Nourished (Fig. 1).

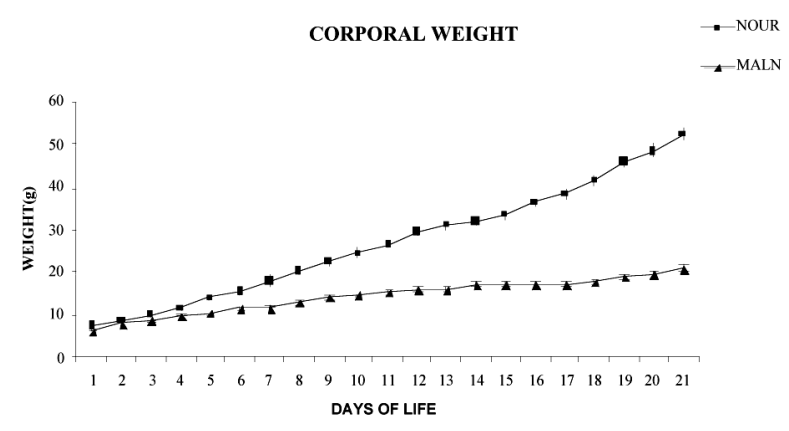

Fig. 1. Effects of malnutrition from $1^{\text {st }}$ to $21^{\text {st }}$ day postnatal on weight evolution of rats. $n=15$ The data are represented as $x \pm S E$ (standard error) of corporal weight in grams. $* \mathrm{p}<0,05$ Nour vs Maln-S (ANOVA followed by the test of multiple comparison of Tukey).

Latero-Lateral Axis of Skull (LLAS). The group Malnourished showed decrease of LLAS when compared with the group Nourished from $8^{\text {th }}$ to $21^{\text {st }}$ day of age $(\mathrm{p}<0,05) \quad$ (Fig. 2).

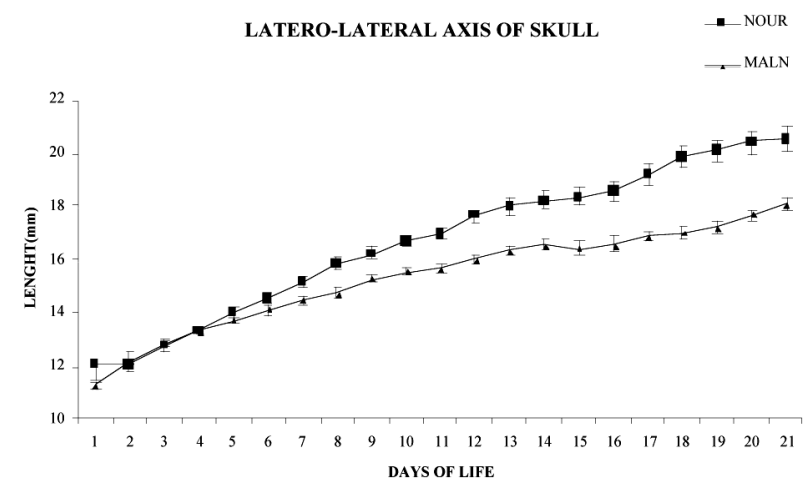

Fig. 2. Effects of malnutrition and/or treatment with fluoxetine from $1^{\text {st }}$ to $21^{\text {st }}$ day postnatal on the length of latero-lateral axis of skull. $n=15$. The data are represented as $x \pm S E$ (standard error) of length of latero-lateral axis in $\mathrm{mm} .{ }^{*} \mathrm{p}<0,05$ Nour-S vs Maln-S ( $8^{\text {th }}$ to $21^{\text {st }}$ day). (ANOVA followed by the test of multiple comparison of Tukey). 
Antero-Posterior Axis of Skull (APAS). In relation to group Nourished, there was a decrease of APAS of group Malnourished from $10^{\text {th }}$ day to $21^{\text {st }}$ day of life $(\mathrm{p}<0,05)$ (Fig. $3)$.

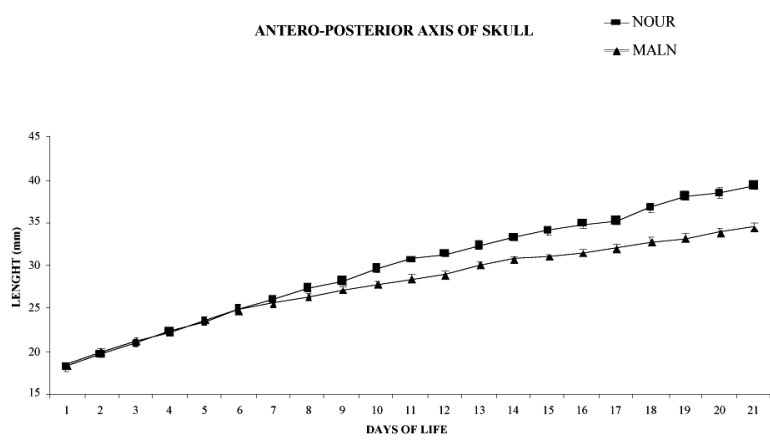

Fig. 3. Effects of malnutrition from $1^{\text {st }}$ to $21^{\text {st }}$ day postnatal on the length of antero-posterior axis of skull. $n=15$. The data are represented as $\mathrm{x} \pm \mathrm{SE}$ (standard error) length of antero-posterior axis of skull in mm. *p<0,05 Nour-S vs Maln-S (10th to 21st day) (ANOVA followed by the test of multiple comparison of Tukey).

Longitudinal Axis (LA). Comparing group Nourished with group Malnourished, it was verified a decrease of LA in group Malnourished from $7^{\text {th }}$ to $21^{\text {st }}$ day $(\mathrm{p}<0,05)$ (Fig. 4).

LONGITUDINAL AXIS

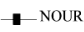

$\triangle$ MALN

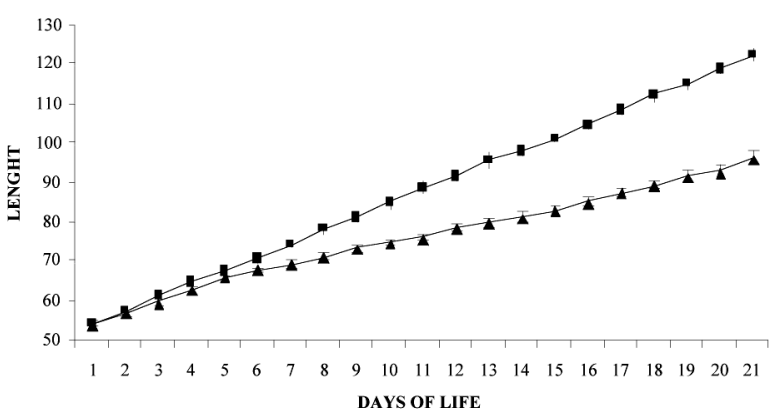

Fig. 4. Effects of malnutrition from $1^{\text {st }}$ to 21 st day postnatal on the length of the longitudinal axis. $n=15$. The data are represented as $x$ \pm SE (standard error) of corporal weight in grams. $* \mathrm{p}<0,05$ Nour vs Maln ( $7^{\text {th }}$ to $21^{\text {st }}$ day) (ANOVA followed by the test of multiple comparison of Tukey).

Length of Tail (LT). The group Malnourished showed a decrease of LT when compared with group Nourished from $7^{\text {th }}$ to $21^{\text {st }}$ day $(\mathrm{p}<0,05)$ (Fig. 5).

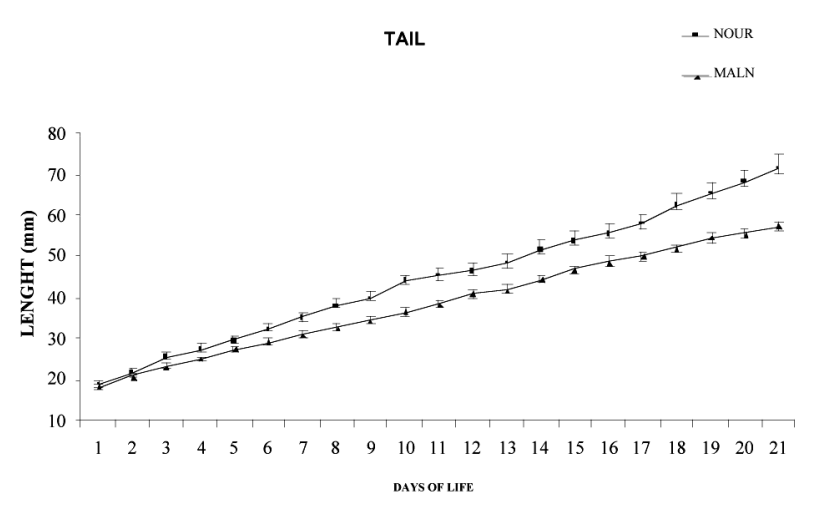

Fig. 5. Effects of malnutrition from 1st to 21st day postnatal on the length of tail. $n=15$. The data are represented as $x \pm S E$ (standard error) of corporal length of tail in mm. ${ }^{*} \mathrm{p}<0,05$ Nour vs Maln (emphasizes the beginning of significant difference (7th to $21 \mathrm{st}$ day) (ANOVA followed by the test of multiple comparison of Tukey).

\section{DISCUSSION}

This study emphasizes the data found in the literature which consider that neonate malnutrition induces the deficit on somatic development of rats.

The model of malnutrition was induced at a moment of depletion of maternal resources common to the final of gestational period and worsened by the high spent energy during the delivery (Morgane et al., 1993; Quek \& Trayhurn, 1990). The nutritional manipulation after the delivery with RBD, a hypoproteic diet (Teodósio et al.) could influence the quality of maternal milk. It was observed in malnourished female nursing rats a decrease on relative quantities of protein (Sturman et al., 1986). This can be worsened by the decrease of size of mammary gland and by the short quantity of milk collected in malnourished female rats that suggests a decrease in the quantity of produced milk (Marín et al., 1995). The perinatal period is seen as physiologic stress also for the neonate (Boxwell et al., 1995). Thus, considering that the rate of increase of weight of young is very high in this period, the lack of a quality feeding will cause a decrease of corporal weight (Resnick et al.).

This work observed a decrease of corporal weight from $4^{\text {th }}$ day postnatal in animals subjected to malnutrition. Similar results were found by Sobotka et al. (1974); Johnson et al. (1991). Studies realized in our laboratory showed a decrease of weight in animals from the same day (Toscano, 2004) and also in an early period, from 2 nd day of life postnatal (Barros, 1999). 
In a previous study using the same experimental model it was observed a higher harm of corporal growth in relation to cranio-encephalic growth. The values of axes of skull were next to control values when compared with values that showed the growth of corporal axes (Barros). This fact was not found in this study that observed a higher uniformity in the results of all investigated axes.

Other studies showed the susceptibility of growth of head in rats subjected to malnutrition on the critical period of development (Oyhenart \& Pucciarelle 1991; Dressino \& Pucciarelli, 1997). The susceptibility of craniofacial skeleton to epigenetic factors like proteic malnutrition was also studied by Miller \& German (1999). The authors found a higher commitment of viscerocranium in relation to neurocranium in rats subjected to nutritional manipulation. Puciarelli (1981) found that the nutritional deficiency delay the growth of chewing region more than respiratory region of skull as well as a lower commitment of neurocranial region compared with respiratory region. However, in this study was found a higher sensitivity to malnutrition in the region linked to neurocranium (LLAS), significant difference from $8^{\text {th }}$ day of life when compared with the region more linked to the viscerocranium (APAS), significant difference from $10^{\text {th }}$ day. Cessani et al. (2003) studying the effect of malnutrition on the development of 3 generations of rats showed that the face is more affected than neurocranium in rats of 1 st generation, however it was observed a higher harm in the neurocranium of rats of $2^{\text {nd }}$ and $3^{\text {rd }}$ generations. The craniofacial development of rat seems to be a more complex process than what was believed before, (Puciarelli) emphasizing the need for establishes more accurate methods to obtain data like the one showed in this work.

It is interesting emphasizes that the answer of proteic malnutrition on the growth of head was started at $2^{\text {nd }}$ week of life postnatal in the two studied axes showing uniformity in the period of harm for these measurements. In an early study previously mentioned, Barros found significant difference from $8^{\text {th }}$ day for LLAS, similar to data showed in this study and from $3^{\text {rd }}$ day for APAS, a period earlier than the ones found in this study.

The definition of anatomic repairs of different studies can explain the found divergence. Barros, to define the methodology of mensuration takes as reference "one media line from the end of muzzle to intersection point with other perpendicular imaginary line. This line is tangent to posterior ends of pinna. The author held the animal using one hand, with its head between the index finger and the thumb, taking the measures with the help of a pachymeter". For this study we used the protocol showed by Silva et al., which suggests: "Hold the animal using one hand, with its head between the index finger and the thumb; locate in the skull of the animal the region of external occipital crest; mark this point with a pen; obtain this measure taking as reference a media line from the end of the muzzle to the marked point of crest, using the scapus of the pachymeter to measure the external ends". The definition of accuracy of pachymeter, $0,02 \mathrm{~mm}$ in our study, suggested by Silva \& Cunha (2003) must be also considered to obtain more accurate measurements.

The data showed here emphasize only one variable of the study of development of head. Other aspects must be also considered in the study of the interference of nutritional manipulation on the craniofacial development. When it were studied more specific points like 24 cranial discontinued traits of skull of rats subjected to proteic malnutrition Dahinten \& Pucciarelli it was found alteration in the intra-frontal fusion, in the palatine foramen posterior and maxillary foramen. The authors emphasized that for the cranial discontinued traits it must be considered not only environmental factors like nutrition but also biologic factors like sex and age. In the maxillofacial complex the malnutrition has an effect in the inter-relation between dental and skeletal age (Gama et al., 2000).

The uniformity in the harm period of nutritional manipulation was also observed in data referred to corporal growth. The effects of malnutrition show significant difference from $7^{\text {th }}$ day for the measures of LA and LT, that is, in the end of $1^{\text {st }}$ week of life postnatal. The literature shows that in rats subjected to hypoproteic diet during lactation period it was observed lost of weight and delay of corporal growth. The decrease of feeding in this period can emphasize the deficit of growth (Cambraia et al., 1997).

In the end of $3^{\text {rd }}$ week of life was observed that in malnourished rats the average of deficit of corporal growth, $21,38 \%$ for LA and 19,89\% for LT, was not proportional to the average of deficit of weight $58,12 \%$. Studies in humans show that malnourished children has lower structure and weight, however, the corporal proportionality is kept (Santos, 1993).

Without the suitable use of scapus of pachymeter suggested by Mandarim-de-Lacerda (1995), to obtain the measures, Barros found significant difference from $6^{\text {th }}$ day for LT and from $5^{\text {th }}$ day for LA. Although also found significant difference next to the end of $1^{\text {st }}$ week of life postnatal, our study seems to emphasize the need of suitable use of scapus of pachymeter to obtain the measures.

The definition of anatomic points to obtain the measures must be also considered in the study of corporal 
growth. To substitute the point "base of tail" used in the study of our laboratory (Deiró, 1998; Barros, 1999; Deiró, 2004) to fix the point of mensuration. It is suggested to substitute it for the "region of anus" showed in the work of Silva et al.

We can conclude that the results of this work confirm the deleterious effects of malnutrition on the somatic development. The use of protocols with definition of anatomic points and choice of suitable material and accuracy of measures showed a higher uniformity in the periods which begins the deleterious effects in all studied axes.

Later studies can use material which provides higher accuracy of data. The use of digital pachymeter with an accuracy of $0,01 \mathrm{~mm}$, in the suggested anatomic points can be added to the protocol in order to clarify the studied data. Previous studies with radiographic cephalometric material (Moss, 1987) showed more objective results and can emphasize the more accurate parameters for the study of harm of malnutrition for the craniofacial growth.

The attention to the line of craniofacial development must be considered in the studies about neurocranium. It must be considered that neurocranium shelters the brain and answers for the development standard of nervous system. Studies about viscerocranium must consider the functional demands (Miller \& German) for example the demands related to the use of chewing musculature, that is important not only to guide the craniofacial growth but also to define new variable and parameters referred to feeding and possibly to nutrition.

SILVA, H. J.; BARROS, K. M. F. T.; CUNHA, D. A.; SANTOS, F. A. S.; SOARES, E. B.; SILVA, C. N. S.; MORAES, S. R. A. \& MANHÃES DE CASTRO, R. Desnutrición y evaluación del desarrollo somático: Uso del protocolo de medidas para la evaluación de los indicadores en ratas Wistar. Int. J. Morphol., 24(3):469-474, 2006.

RESUMEN: Evaluamos las repercusiones de la desnutrición y/o de la manipulación serotoninérgica, durante el período de crecimiento rápido del encéfalo, en el desarrollo somático en ratas. Para esto, fue utilizado el protocolo de medidas de indicadores de desarrollo propuesto por Silva et al., 2005. El protocolo fue aplicado del $1^{\mathrm{er}}$ al $21^{\circ}$ día. Las ratas fueron amamantadas por madres que recibieron dieta controlada (dieta comercial, Labina) normoproteica con $23 \%$ de proteínas (Grupo Nutrido - Nut), $n=15$, o fueron amamantados por madres que después del parto recibieron dieta hipoprotéica (Dieta Básica Regional - DBR), conteniendo 8\% de proteína (Grupo Desnutrido - Desn), $\mathrm{n}=15$. En el grupo desnutrido fueron observadas reducciones en el peso corporal a partir del $4^{\circ}$ día, en el eje látero-lateral del cráneo del $8^{\circ}$ al $21^{\circ}$ día de vida, en el eje ántero-posterior del cráneo del $10^{\circ}$ al $21^{\circ}$ día, en el eje longitudinal y en la cola del $7^{\circ} \mathrm{al} 21^{\circ}$ día $(\mathrm{p}=0.05)$. El estudio ratificó la hipótesis que la desnutrición, en el período crítico del desarrollo, interviene con el crecimiento somático de las ratas. Por otra parte, fue comprobado que el uso de protocolos con la definición de puntos anatómicos y precisión de las medidas, proporcionan una uniformidad en los períodos en que son observados los efectos deletéreos estudiados.

\section{PALABRAS CLAVE: Desnutrición; Desarrollo somático; Ratas Wistar.}

\section{REFERENCES}

Barros, K. M. F. T. Efeitos da desnutrição neonatal elou do tratamento com agonista 5-HT 1A sobre o desenvolvimento sensório-motor e atividade exploratória em ratos. 1999. 107f. Dissertação (Mestrado em Bases Experimentais), Departamento de Nutrição, Universidade Federal de Pernambuco, Recife, 1999.

Benefice, E.; Fouere, T. \& Malina, R. M. Early nutritional history and motor performance of Senegalese children, 4-6 years of age. Ann. Hum. Biol., 26(5): 443-55, 1999.

Boxwell, J.; Ayson, P. \& Ramenofsky, M. Growth and metabolic parameters in pups of undernourished lactating rats. Physiology and Behavior, 57(3):469-75, 1995.

Cambraia, R. P. B; Vannucchi, H; Oliveira, L. M. Food intake and weight of lactating rats maintained on different protein-calorie diets, and pup growth. Braz. J. Med. Biol. Res., 30(8):985-8, 1997.
Cessani, M. F.; Orden, B.; Zucchi, M.; Muñe, M. C.; Oyhenart, E. E. \& Pucciarelli, H. M. Effect of Undernutrition on the Cranial Growth of the Rat. Cells Tissues Organs, 174:129-35, 2003.

Chen, J. C.; Tokins, J.; Galller, J. R. \& Vociler, L. Effect of prenatal malnutrition on release of monoamines from hippocampal slices. Life Sciences, 57:1467-75, 1995.

Dahinten, S. L. \& Pucciarelli, H. M. Effect of age, sex and nutrition on discontinuous traits of rat skull. Acta Anat., 110(2):159-63, 1981.

Deiró, T. C. B. J.; Manhães-De-Castro, R.; Cabral-Filho J. E.; Souza, S. L. ; Freitas-Silva S. R.; Ferreira, L. M. P.; Guedes, R. C. A., Câmara, C. R.V. \& Barros K. M. F. T. Neonatal administration of citalopram delays somatic maturation in rats. Braz. J. Med. Biol. Res., 37(10):1503-9, 2004. 
Deiró, T. C. B. J. Desenvolvimento somático e sensório-motor e padrão adulto do consumo alimentar, em ratos: efeitos do tratamento neonatal com inibidor de recaptação da serotonina durante o período de crescimento rápido de encéfalo. 1998. 101f. Dissertação (Mestrado em Bases Experimentais)-Departamento de Nutrição, Universidade Federal de Pernambuco, Recife, 1998.

Dressino V. \& Pucciarelli, H. M. Cranial growth in Saimiri sciureus (Cebidae) and its alteration by nutritional factors: A longitudinal study. Am. J. Phys. Anthropol., 102:545-54, 1997.

Frank, S. Metabolic adaptation in protein-energy malnutrition. J. Am. Coll. Nutr., 5:371-81, 1986.

Gama, F. V. A.; Soviero, V. M.; Bastos, E. P. S.; Vianna, R. \& Souza, I. P. R. O efeito da desnutricäo no desenvolvimento maxilofacial. Nutrition disorders effect on the maxillofacial development. Rev. ABO Nac., 8(2):108-10, 2000.

Granthan-McgGregor, Schofield, W. \& Powell, C. Development of severely malnourished children who received psychosocial stimulation: six-year follow up. Pediatrics, 79(2): 247-54. 1987.

Johnson, J. D.; Wogenrich, W. J.; Hsi, K.C.; Skipper, B. J. \& Greenberg, R. E. Growth retardation during the suckling period in expanded litters of rats: observations of growth patterns and protein turnover. Grow. Develop. Agng., 55:263-73, 1991.

Levitsky, D. A. \& Barnes, R. H. Nutritional and enviromental interactions in the development of the rat: Long-term effects. Science, 176:68-71, 1972.

Mandarim-de-Lacerda, C.A. Métodos quantitativos em morfologia. São Paulo, Eduerj, 1995. 131pp.

Marín, M. C.; Tomás, M. E. Serres, C. \& Mercuri, O. Protein-energy malnutrition during gestation and lactation in rats affects growth rate, brain development and essential fatty acid metabolism. $J$. Nutr., 125:1017-24, 1995.

Miller, J. P.; German R. Z. Protein Malnutrition Affects the Growth Trajectories of the Craniofacial Skeleton in Rats. J. Nut., 129:2061-9.1999.

Morgane, P. J.; Austin-LaFrance, R.; Bronzino, J.; Tonkinss, J.; DíazCintra, S.; Cintra, L.; Kemper, T.; Galler, J. R.et al. Prenatal malnutrition and development of the brain. Neurosc. Biobeh. Rev., 17:91-128, 1993.

Moss, M. L,; Vilmann, H.; Moss-Salentijn, L.; Sen, K.; Pucciarelli, H. M. \& Skalak, R. Studies on orthocephalization: growth behavior of the rat skull in the period 13-49 days as described by the finite element method. Am. J. Phys. Anthropol., 72(3):32342, 1987.

Oyhenart, E. E. \& Pucciarelle, H. M. The influence of gonadic hormones on skull differences in rats malnoureshed during lactation. Acta Physiol. Pharmacol. Ther Latinoam., 41(3): 8793, 1991
Pucciarelli, H. M. Growth of the functional components of the rat skull and its alteration by nutritional effects. A multivariate analysis. Am. J. Phys. Anthropol., 56(1):33-41, 1981.

Quek, V. S. \& Trayhurn, P. Calorimetric stydy of the energetics of pregnancy in golden hamsters. Am. J. Physiol., 259:807-12, 1990.

Resnick, O.; Miller, M.; Forbes, W.; Hall, R. Kemper, T.; Bronzino, J. \& Morgane, P. J. Developmental protein malnutrition: influences on the central nervous system of the rat. Neurosc. Biobeh. Rev., 3:233-46, 1979.

Rooso, P.; Hormazábal, J. \& Winick, M. Changes in brain weight, cholesterol, phospholipid and DNA cotent in marasmatic children. Am. J. Clin. Nutrition., 23(10):1275 -9, 1970.

Santos, R. V. Crescimento físico e estado nutricional de populacoes indígenas brasileiras / Physical growth and nutritional status of brazilian indian populations. Cad. Saúde Pública, 9(supl.1):4657, 1993.

Silva, H. J.; Marinho, S. M. O.; Silva, A. E. T.; Albuquerque, C. G.; Moraes, S. R. A. \& Manhães De Castro, R. Protocol toa valiation of indicators of somatic development os wistar rats. Int. J. Morphol., 23(3):227-30, 2005.

Silva, H. J. \& Cunha D. A. Considerações sobre o uso do paquímetro em motricidade oral. Rev. Fono. Brasil, 2:59-64, 2003.

Smart, J. L. \& Dobbing, J. Vulnerability of developing brain. II. Effects of early nutritional deprivation on reflex ontogeny and development of behavior in the rat. Brain Research, 28(1), 1971.

Sobotka, T. J.; Cook, M. P. \& Brodie, R.E. Neonatal malnutrition: neurochemical, hormonal and behavioral manifestations. Brain Resarch, 65:443-57, 1974.

Sturman, J. A.; Devine, E.; Resnick, O. \& Morgane, P. J. Maternal protein malnutrition in the rat: effect on protein and two enzymes in the milk. Nutr. Res., 6:437-42, 1986.

Teodósio, N. R.; Lago, E. S.; Romani, S. A. M.; Guedes, R. C. A. A regional basic diet from northeast Brazil as a dietary model of experimental malnutrition. Arch. Latinoam. Nutr., 45(4):533-45, 1990.

Toscano, A. E. Desnutrição e manipulação serotoninérgica neonatais: repercussões sobre o desenvolvimento da morfologia cardíaca. Dissertação (Mestrado), Departamento de Nutrição Universidade Federal de Pernambuco, 2004. 106pp

Corresponce to:

Hilton Justino da Silva

Rua São Salvador, 105, Ap 1002

CEP 54720-000

Graças Recife-Pernambuco

BRASIL

Email: hiltonfono@hotmail.com

Recibido : 17-04-2006 Aceptado: 26-07-2006 